\section{Internal Fixed-Target Experiment for HERA}

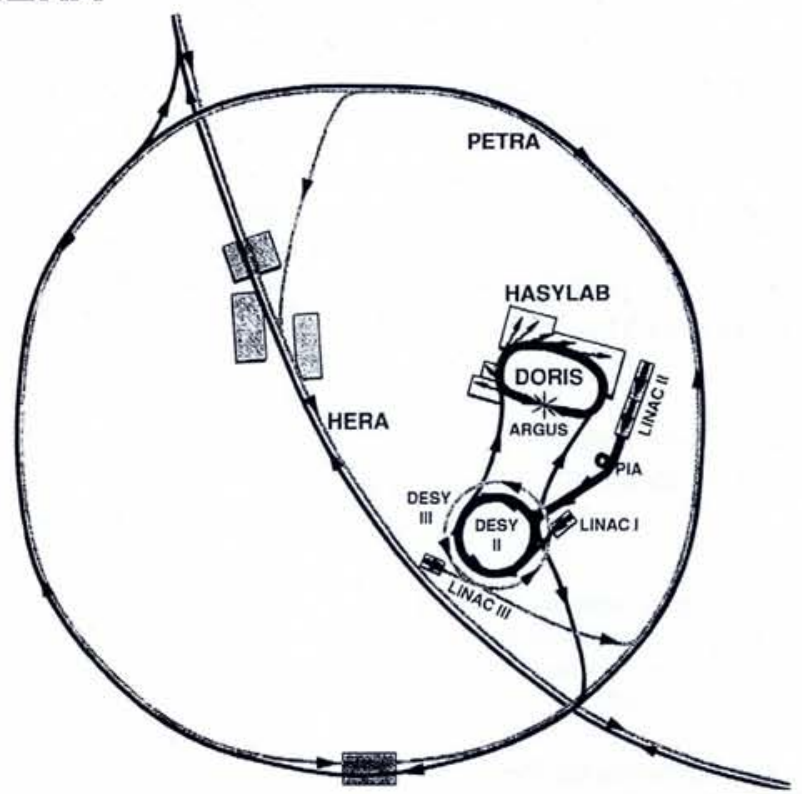

The accelerator complex at the Deutsches Elektronen-Synchrotron (DESY) in Hamburg.

ARGUS, the last of two high-energy physics experiments at DESY's DORIS ring in Hamburg, is to be closed down after 10 years of datataking. This was decided unanimously by the ARGUS Collaboration partly because the experiment has become uncompetitive compared to Cornell's $5.3 \mathrm{GeV} /$ beam CESR machine. Factors included the requirements for injection into the new HERA electron-proton collider and the need to optimise operation following modifications, completed in 1991, to DORIS to increase synchrotron radiation facilities at the HASYLAB source.

B. Wiik, DESY's Director-General, indicated at the ICFA Seminar on 6 May that HASYLAB users (presently some 650 at 28 stations) will outstrip users of high-energy physics experiments in a few years. An undulator source, mounted at the high-energy ring PETRA, with a brilliance above that found at a large third-generation synchrotron source such as the ESRF (see page 81 ) will be available in 2-3 years.

The DESY Directorate agreed this month that an internal fixedtarget experiment at the HERA proton ring can be proposed for HERA's fourth interaction point. HERA already has two experiments in operation ( $\mathrm{H} 1$ and ZEUS) involving 340 and 430 collaborators, respectively. HERMES, a polarized electron/gas jet target experiment, will start datataking in 1995 (the large forward spectrometer is under construction in Heidelberg).

The ARGUS team will be involved in planning the new experiment, which is for B-meson physics with the study of $\mathrm{cp}$-violation as the main aim. It should eventually involve a collaboration of roughly the same size as HERMES (150 collaborators). Approval by the DESY Directorate is hoped for next year subject to funding and technical feasibility; B. Wiik indicated that datataking "could probably start" in 1997. The nice thing about the new experiment is that the internal target comprising an arrangement of wires (see figure) lies in the halo of the circulating proton beam so it does not take away luminosity or add much background. The experiment is, in principle, simple and the effects large. It has been known for some time that the main problem will be to detect an adequate number of relevant events from among many others. The proposal will be submitted to DESY's research council shortly after a workshop at DESY on 21-23 September 1993 on fixed-target experiments.
The layout of the internal wire target experiment to be proposed for HERA.

\section{Physics Hypertext CD-ROM Available}

Hypertext means non-sequential writing and reading via a multidimensional text, with junctions for burrowing for details, definitions and background data; hypermedia is an extension to include graphics, sound, etc. R.G. Fuller of Nebraska University, USA, said at the 1992 Millikan Lecture on physics teaching [1] that "so far we have not seen much use of hypermedia in classrooms" although it is "an important topic of discussion at corporate training conferences". His Physics Teachers CD-ROM Toolkit Project has developed a CD-ROM disc called Physics InfoMall to bring hypermedia to physics classrooms. Some 450 copies of the first batch have been field tested and a second batch of 700 is available. One needs a CD-ROM drive on a Macintosh or a PC with Windows, and the disc is now available (for SUS 30.-) for field testing in Europe [2]. IOP Publishing in the UK plans demonstrations [3] with a view to full commercial service.

The disc comprises a collection of teaching resources including 8 textbooks (essentially US), 5 reference books, selected journal articles, and several dictionaries, etc. - some 300000 pages in all. Software is included to guide teachers and students while they, for instance, "cut and paste" together a report.

Fabio Bevilacqua of Pavia University, who chairs the EPS Interdivisional Group on the History of Physics, has been involved in teaching using hypermedia approaches applied to the history of physics. He felt InfoMall is good value and stressed the need to rework printed materials within the framework of learning theory. For example, conceptual mapping provides a way to balance the analytical aspects of digitalisation (hypertext links, quantitative simulations, graphical representation of equations) with special effects (sound, animations, etc.).

[1] R.G. Fuller, Am. J. Phys. 61 (1993) 300; fax: +1-402-472 6234

[2] Physics InfoMall field testing application: contact Physics InfoMall, Physics Dept., Cardwell Hall, Kansas State Univ., Manhattan, KS 66506-2601, USA. Price: \$US 30.-; testers are asked to report back. [3] Contact: Alan Singleton, IOPP Ltd., Techno House, Redcliffe Way, Bristol BS1 6NX, UK (tel./fax. +44-272-29 7481 / 2943 18).

\section{Hahn-Meitner-Institut Berlin $\mathrm{GmbH}$}

Das HMI ist eine Großforschungseinrichtung der Bundesrepublik Deutschland und des Landes Berlin mit rund 850 Beschäftigten. Standorte: Berlin-Wannsee und Berlin-Adlershof.

Schwerpunkte der Arbeit sind Grundlagenforschungen zur atomaren und molekularen Struktur von Materie sowie zur photochemischen und photovoltaischen Umwandlung von Sonnenenergie. Als Methode der Strukturforschung wird unter anderem Ionenund Neutronenstrahlung genutzt.

Kennziffer $\mathrm{N} 93.12$

Der Bereich Strukturforschung - Standort Wannsee sucht eine/n

\section{Diplom-Physiker/in}

Vgr. lla BAT. Zeitvertrag aber drei Jahre. Aufgabengebiet: Neutronenreflektometrie.

Anforderungen: møglichst Promotion; Erfahrung auf den Gebieten Röntgenstreuung, Neutronenstreuung, experimentelle Festkörperphysik oder dünne Schichten.

Der HochschulabschluB soll zum Zeitpunkt des Vertragsabschlusses nicht lănger als vier Jahre zurückliegen (AGF-Nachwuchswissenschaftler-Programm).

Wir bemähen uns, den Anteil von Frauen an wissenschaftlichem Personal zu erhöhen, und sind daher an der Bewerbung geeigneter Frauen besonders interessiert. Schwerbehinderte werden bei gleicher Qualifikation bevorzugt.

Ihre Bewerbung richten Sie bitte schriftlich unter Angabe der Kennziffer bis zum 31. Mai 1993 an das

Hahn-Meitner-Institut Berlin GmbH, V1, Glienicker StraBe 100, 1000 Berlin 39. 